\title{
The Divided Mind of James Baldwin
}

\author{
C. W. E. BIGSBY
}

Lionel Trilling once observed that there are certain individuals who contain the "yes" and "no" of their culture, whose personal ambivalences become paradigmatic. This would seem to be an apt description of a man whose first novel was published twenty-five years ago, a man whose career has described a neat and telling parabola and whose contradictions go to the heart of an issue which dominated the political and cultural life of mid-century America: James Baldwin. And it is perhaps not inappropriate to seize the occasion of this anniversary and of the publication of his new novel, Just Above My Head, to attempt a summation of a writer, once an articulate spokesman for black revolt, now living an expatriate existence in southern France.

To date, Baldwin has written six novels: Go Tell it on the Mountain (1954), Giovanni's Room (1956), Another Country (1962), Tell Me How Long the Train's Been Gone (1968), If Beale Street Could Talk (1974), Just Above My Head (1979); four books of essays: The Fire Next Time (1963), Nobody Knows My Name (1964), Notes of a Native Son (1964), No Name in the Street (1972); two plays: Blues for Mr. Charlie (1964), Amen Corner (1968); and one book of short stories: Going to Meet the Man (1965). Born in Harlem in 1924 , he left in 1948 for France, driven out by despair of the racial situation. He returned in 1957 and in the heady days of the Civil Rights movement found himself a principal spokesman - his polemical essay, The Fire Next Time, appearing at a crucial moment in black/white relations. Outflanked by the events of the late sixties, he retreated again to Europe. His more recent novels have failed to spark the popular or critical interest of his earlier work.

What follows is not offered as a detailed critical analysis of his literary work but as an account of a career and a mind instructively divided, a sensibility drawn in opposing directions.

Dr. C. W. E. Bigsby is Reader in American Literature in the School of English and American Studies, University of East Anglia, Norwich.

Amer. Stud. 13, 3, 325-342 Printed in Great Britain 002 I-8758/79/BAAS-3001 \$01.50 (C) 1979 Cambridge University Press 
James Baldwin spent the first part of his career compensating for his deprivation and the second part compensating for his success. He sought invisibility in racial terms by going to Paris, and ended up by becoming the most visible black writer of his generation. His career was in part generated by the rise of the Civil Rights movement, as white America looked for an explanation for the crisis which had apparently arrived so suddenly; and it was eventually threatened by that movement, which in time produced demands for racial and aesthetic orthodoxy which potentially left him stranded in his equivocal role as mediator and prophet, when the dominant model for black art became fierce commitment and cultural separatism. Having fled a role as writer and individual which was determined by the colour of his skin, he discovered that that colour was in fact to be the key to his art. Wishing to dispense early with the obligation to act as spokesman, he came to recognize a responsibility to articulate, if not the demands, then the feelings of those whose own frustrations and courage were otherwise expressed in mute suffering or simple action. What Baldwin has become he once travelled four thousand miles not to be.

Both the act of refusal and the ultimate acceptance are characteristic gestures of a writer who has always been drawn in two apparently mutually incompatible directions. It was not simply that his early faith in the moral responsibility of the individual and the possibility of social change was destroyed, though he has said as much: "There was a time in my life not so very long ago that I believed, hoped... that this country could become what it has always presented as what it wanted to become. But I'm sorry, no matter how this may sound: when Martin was murdered for me that hope ended." It is that from the very beginning the optative mood had been in battle with a sullen determinism, the present tense constantly invaded by the past. Catonian warnings in his work have alternated with expressions of sensual salvation. His has indeed always been a schizophrenic style, as he has in turn presented himself as suffering black and alienated American, social outcast and native son. It is a rhetorical style which at its best captured the cadences of hope and rebellion which characterized the early days of the civil rights movement, and which at its worst degenerated into unashamed posturing of a kind which failed to inspect with genuine moral honesty the realities which he had once exposed with such authority.

For Baldwin, the self is sometimes a series of improvizational gestures and sometimes a moral constant which has only to be exposed to become operative. And there is at the heart of his work, beneath the level of contingent event and social determinant, an unexamined confidence in the

1 James Baldwin and Margaret Mead, $A$ Rap on Race (London: 1972), pp. 245-46. 
possibility of action and the recovery of ethical purpose. Constraints are arbitrary and irrational; hatred and rage the product of a history which is real but susceptible of transcendence. Though assailed from within and without by a corrosive mythology, the individual consciousness contains resources entirely adequate to the task of distilling meaning from social chaos, while the alliance of consciousnesses provides the principal means of resisting an isolation which is part social and part metaphysical.

At the heart of his work is a Christian belief that grace is a gift of suffering and that love has the power to annihilate the primal space between the self and its perception of itself, between the individual and the group. Racial and national categories, though real and though reflecting a symbolic heritage, exist to be transcended, for he is convinced that society clings so desperately to rigid definitions - sexual and social - more from a need to project a sense of order than from a belief that such distinctions contain any real clue to the nature of human possibilities. The Negro, in fact, is in large part a fiction, a convenient hierarchical invention. As an emblem of unrepressed needs and of uninhibited sexuality, he becomes a convenient image of the dark, spontaneous and anarchic dimension of human life. His social subordination thus stands as a symbol of society's control over its own anarchic impulses. As a consequence he is offered a role whose significance is not limited to its social utility. Thus, when he resists that caricature the consequent appeals by the dominant society to "law and order" have metaphysical as well as pragmatic implications.

In Baldwin's work the self resists the peripheral role which seems its social fate, and the primary agent in this resistance is the imagination. It is an imagination with the necessary power to project alternative worlds, to conceive of a society which can escape its own myths and consciously break its own taboos. The communicative act involved in art (virtually all of his protagonists are artists of one kind or another, including musicians, actors and novelists) becomes in itself a paradigm of a desired social interaction, while the individual's imposition of order, implied by the creative act, becomes a model for a coherence which is generated by the sensibility and not imposed by social fiat. And this presumption of an imaginative control of the world necessarily implies a rejection of that religion which historically has proved a secondary means of social control. Rejection of God is a natural extension of rebellion against the power of the state.

There is a demonstrable logic of revolt. The creation of an autonomous self relies first on a rejection of the authority of the father (his personal revolt against his father recurs in his work) and then that of white society and of God. The self emerges, in a familiar liberal way, by a slow rejection 
of elements extraneous to that self. Such a process frequently involves pain and Baldwin remains enough of a puritan to believe that this is a key to truth. But salvation, paradoxically, lies in a leap from belief into scepticism. Baldwin replaces the authority of social and metaphysical dictat with an authority of the sensibility. Faith gives way to a secular belief in the authenticating power of the self.

Baldwin's characters are highly self-conscious, reflecting not only upon their social situation but on the nature of their consciousness itself. The question of identity is constantly presented to them. Indeed, it is often a clue to literal survival, so that it becomes in itself a literary event. And the particular problem which confronts them is that the usual stratagems of definition now fail. History, memory and belief are at odds with the drive for self-creation and the need for personal alliances which can deny the reality of boundaries. Thus his characters tend to adopt an ambiguous stance with regard to time, appropriating to themselves the right to define process and resist versions of historical progress which threaten to subordinate them to an alien logic.

His use of the internal monologue itself implies the existence of a resistant self which is apart from and not contained by the externalities which otherwise seem to define the limits of action and character. This is the functioning imagination, the artist within, which creates even as it analyses. His are not novels which are primarily concerned with social change in the sense of a re-allocation of power; what matters to him is the altered consciousness of the individual. $\mathrm{He}$ is interested in process, in the interplay between the experiential and the given. The stream of consciousness becomes an image for the flow of experience and responses which provide the basis for a definition of the self. And, indeed, in a sense, one can find in William James's discussion of the stream of consciousness a justification for Baldwin's attempt to have his cake and eat it; his feeling that the self is both its own creation and an existent fact which has merely to be exposed to another level of consciousness. In The Principles of Psychology William James says that, "if the stream as a whole is identified with the self far more than any outward thing, a certain portion of the stream abstracted from the rest is so identified in an altogether peculiar degree, and is felt by all men as a sort of innermost centre within the circle, of sanctuary within the citadel constituted by the subjective life as a whole." ${ }^{2}$ For Baldwin this is less a spiritual essence than a sense of moral certainty, an intimate reality available to the individual who learns the necessity to engage experience with a sensibility undistorted by social presumptions.

2 Quoted in Frederick Hoffman, The Mortal No (Princeton: 1964), p. 332. 
The problem which Baldwin fails to engage is precisely how that integrity of the self can be projected onto a social scale; why the withdrawal into love should be seen as an adequate model for social action since it is frequently born out of a denial of that social action. This is something which he largely leaves to his essays. Baldwin can dramatize the moment and even the process which results in that moment; but he is, for the most part, unable to sustain that moment to the point at which it becomes an enabling strategy. The impersonal power which limits individuality seems too immune to such epiphanies to grant anything but momentary release from its definitional authority.

For Norman Mailer, the world can be made over by the personality, which can counterpose its own energies to that of society and which can release a neutralizing flood of language which, in effect, reduces the physical world to the status of backdrop: the subject of the drama is the self, the social world existing only in so far as the individual is prepared to grant it a role. Personal history becomes as authentic as public history. But for Baldwin history cannot be shrugged off with such a casual gesture. His lack of social freedom, as a Negro, contrasts markedly with that of a man who can seriously run for the office of Mayor of New York, and who apparently has a kind of romantic faith in the fact that social forms are plastic enough to be moulded by the sheer power of the will. As Baldwin has never tired of telling people, the black American knows otherwise. $\mathrm{He}$ is all too aware of the injunctions, written and unwritten, which spell out the limits of his freedom; to cross those boundaries is to risk a reaction which is real in the sense of Dr. Johnson's definition of the term. Yet in fact he himself was tempted by solutions every bit as romantic as those advanced by Mailer, and his commitment to invoking the sinister lessons of history is always balanced by a contrary faith in a grace which can dissolve such determinism.

In his attack on Baldwin, in Advertisements for Myself, Mailer accused him of not being able to say "Fuck you" to the reader. It was an even more naive remark than it seemed in that it failed to recognize that sense of oppression from which Mailer was immune but which had led Baldwin to be a writer; it also failed to recognize that all of his work was in effect an attempt to discover a basis on which such a contemptuous dismissal of society could be effectuated, while longing, as LeRoi Jones and Eldridge Cleaver cruelly pointed out, for precisely that gesture of inclusion which would obviate such a response.

For Baldwin, will, crucially allied with imagination and a sensitivity to the pressure of other selves, becomes a force with the power, if not to over- 
come social realities, then to forge other alliances than those sanctioned by history and power. But this is not quite the confident self of the transcendentalists. In each of his books self-analysis is not only provoked by pain; it is the source of pain. Society's power is scarcely diminished. The most that the individual can hope for is to win a small psychic territory within which the harsh pragmatics of the public world no longer operate. Nor is love quite the panacea which it appears, for it, too, is infected by materialism, by the urge to power and by the demands of history and myth. And though, as suggested above, Baldwin is never clear as to whether identity is laboriously constructed out of the interplay of sensibility and event, or whether it is a resilient moral principle concealed beneath social habiliments, in neither sense is he confident of its ability to command public acquiescence. (And this, of course, is the source of the pressure which led him to social protest outside of his novels. As a public spokesman he sought to provoke changes which would allow greater space for the self which, as a novelist, he felt was the real agent of transformation.)

Like Emerson and Thoreau he felt the need to resist those conventions and beliefs which passed for an adequate description of the real, in favour of a spiritual self-reliance, limited only by its obligations to remake the public world, whose deceptions and inadequacies were rejected not in the name of privatism but of truth. But Baldwin inhabits a more sceptical world and his racial identity is forced to concede more power to social fictions than was that of the New England moralist.

In a sense, of course, America has always prided itself on its improvizational qualities, and in his essays Baldwin has repeatedly insisted on the parallel between the Negro in search of selfhood and the American intent on distilling a national identity. And he was clearly right in insisting on his American-ness. It is stamped on his imaginative enterprise. But the fluidities of the American system have historically not extended to the Negro. On this the country had been absolute. Where everything else has changed, to Baldwin this at least has remained a constant. And in this respect the experience of black and white is dissimilar. Certainly the irony of Baldwin claiming an American heritage in his early books of essays at the moment when facilities in southern towns, which he himself was not to visit until his early thirties, were still segregated, was not lost on his critics. Yet Baldwin's view was that though American identity and history had indeed been built on a denial of human complexity and freedom, this was a denial of an essential American idealism to which he wished to lay claim. His resistance to protest fiction (see "Everybody's Protest Novel ") and, implicitly, to the naturalistic novel, lay precisely in the fact that it 
denied access to this idealism, that it made the self into a simple product of biological and environmental determinism. It denied the possibility of escape. And that, arguably, is at the heart of Baldwin's work: the need to forge a truce with determinism and with punishing social constraints, a truce which can sustain the individual even, perhaps, in face of the knowledge of its inevitable collapse. The escape to Europe is simply an attempt to create geographically that space for manoeuvre which in America has to be won through an exertion of imagination or will.

But the ironies emanating from his American identity were not simply those contained in the obvious dissonance between American idealism and reality. As he himself fully realized, his very articulateness is itself fraught with ambiguities which seem to nail him permanently to a paradoxical view of self and cultural identity. Indeed, Baldwin has always been aware of the special problem of language for the black writer. "It is quite possible to say that the price a Negro pays for becoming articulate is to find himself, at length, with nothing to be articulate about." ${ }^{3}$ The word becomes a barrier, indeed a protection, between the self and experience. The reduction of social event to language becomes in itself a form of escape. Initially, experience intervenes between the self and the articulation of that experience, but in turn language intervenes between the self and the experience. $\mathrm{He}$ is crushed from two directions.

"The root function of language," Baldwin suggests, " is to control the universe by describing it." " But the black finds that access to language is not access to power, to control over his environment or himself. Language becomes disfunctional. Historically, of course, it betrayed him more fully into the power of those who sought to control him by offering means to facilitate that control. And once in possession of that language he becomes, perforce, heir to those very cultural presumptions to which he is formally denied free access. In turn he is then blessed or fated with a fluency which draws him steadily away from his own past. He is thus left with a cultural inheritance characterized by ambiguity, self-doubt, and linguistic paradox. And Baldwin's work carries this mark. The personal pronoun, as he applies it, in Nobody Knows My Name and Notes of a Native Son, means sometimes Negro and sometimes American, a pronominal uncertainty which goes to the heart of that concern with identity which characterizes so many of his essays and so much of his work. And when he assumes an identification with his American self against his racial identity the effect is more ambivalent. For the cultural nationalists of the sixties his assertion that "Our dehumanization of the Negro... is indivisible from our de-

3 James Baldwin, Notes of a Native Son (London: 1965), p. 3 .

4 Ibid., p. 14I. 
humanization of ourselves: the loss of our identity is the price we pay for our annulment of his," 5 is an expression of a desire for cultural assimilation which goes beyond a rhetorical device.

His rhetorical style, particularly that of the latter part of his career, is, in fact, a product of the battle to enforce his authority over language, to make it accommodate itself to an experience which it had been designed to justify and impose. As he put it, "you've simply got to force the language to pay attention to you in order to exist in it." "The central problem, as he explained to Margaret Mead in 1970, was "how are we ever going to achieve some kind of language which will make my experience articulate to you and yours to me? Because you and I have been involved for all our lives ... in some effort of translation." ?

Protest was implied in Baldwin's stance as an essayist. He was indeed a mediator, explaining the Negro to America by translating his experience into American terms, by establishing his own struggle for identity as of a kind with that of the American, anxious to distil meaning from history and experience. Like Ralph Ellison, he is essentially calling for the restoration of American idealism, and sees the route to that as lying through the individual: "An honest examination of the national life proves how far we are from the standard of human freedom with which we began. The recovery of this standard demands of everyone who loves this country a hard look at himself, for the greatest achievements must begin somewhere, and they always begin with the person." 8

His trip to Paris in 1948 was an American search for personal and national identity in an Old World which could render up an image of the New partly from its own desire to translate promise and threat into concrete form, and partly from its own ability to conceive of an America luminous with a meaning derived from those very contradictions which the American writer frequently found so disabling. In part, of course, it was the old game of disoovering the limits of the self by abstracting it from the viscous world of its daily setting; it was an attempt to see what could survive such spiritual surgery - an act of definition by elimination, an attempt to find which conflicts were internal and definitional and which part of a dialectic between the unexamined self and the social projections of that self. For a black American it afforded the only opportunity to venture outside of the myth which defined him, and, in a curious way, protected him, in so far as it offered a self-image requiring only acceptance. Here, as Baldwin knew, he would be judged for himself, or at least in the context of other com-

5 Ibid., p. I9.

6 Baldwin and Mead, A Rap on Race, p. $5^{8 .}$

7 Ibid., p. 180 .

8 James Baldwin, Nobody Knows My Name (London: 1965), p. 98. 
pulsions than the familiar ones. Yet it was as an American that he found himself responding, as an American that Europeans perceived him. And what he learned was the impossibility of distinguishing a clear line between the self and the culture in which that self develops. Once in Europe he felt as "American as any Texas G.I.," freed from the necessary reflexes which had once concealed his own identity from others and hence, eventually, from himself.

It was a move which sprang from the conviction that neither an unquestioned community of suffering, nor an assumed American homogeneity, offered a real clue to personal meaning. Baldwin wanted to find out " in what way the specialness of [his] experience could be made to connect [him] with other people instead of dividing [him] from them." 9 And that specialness could only be abstracted by removing himself from a culture whose definitions of him sprang from compulsions shaped partly by history and partly by the pressure of a perverted puritanism and a hermeneutic of suffering and guilt.

"Everybody's Protest Novel" was not so much a necessary assault on a major icon of black literature as it was an expression of his desire to resist the role which he could feel being pressed upon him. To be a Negro writer was to be reduced to a socio-literary category. His subject was not just himself, in the sense that it always is for the writer, it was himself as Negro. And his assault on the protest novel was an attempt to create sufficient space for himself to operate, outside of the terms which it seemed his fate to embrace. As he said in the introduction to his early book of essays, Notes of a Native Son, "I have not written about being a Negro at such length because I expect that to be my only subject, but only because it was the gate I had to unlock before I could hope to write about anything else." ${ }^{10}$ At the beginning of his career, already writing his first novel, he felt the need to establish his own right to be seen outside the terms which seemed to mark the limits prescribed for the black novelist, by white society on the one hand, and by the moral demands of black suffering on the other.

He reacted against the Bigger Thomas of Richard Wright's Native Son, he admitted, partly because he seemed to him to represent a possibility which had to be rejected if he was to escape a self-destructive rage. In an early story, called "Previous Condition," published in I948, he displaces this violence into the imagination of his protagonist: "I wanted to kill her, I watched her stupid, wrinkled frightened white face and I wanted to take a club, a hatchet, and bring it down with all my weight, splitting

9 Ibid., p. 17.

10 Baldwin, Notes of a Native Son, p. 5. 
her skull down the middle where she parted her iron-grey hair." 11 But Baldwin is less interested in the literal discharge of hatred than in its power to distort the psyche, to warp personal and private history. It was precisely to escape such a distortion that he fled to Europe, a process which he describes in "This Morning, This Evening, So Soon," published in Going to Meet the Man, which remains one of his best stories and one which is crucial to an understanding of his position.

It concerns a black American actor/singer who lives in France with a Swedish woman, Harriet, and their son, and is in part an explanation of the sense of release which expatriation granted to him. For though he concedes a determining power to race, religion and nationality, the story is offered as evidence of the fact that such determinants are deadly if they are not transcended: " everyone's life begins on a level where races, armies, and churches stop." 12 And the gift of ex-patriation is precisely such a transcendence, for it enables individuals to confront themselves and others outside of the constraining power of myth.

Black men and white women free themselves of a public rage and coercive power which, in America, would have become private compulsions. They are also free of a language which might otherwise throw its own reductive net around them. As the protagonist's sister observes, "Language is experience and language is power." 13 The failure of black Americans, as she sees it, is that they employ a language of power which must be ironic since it is detached from their experience. And yet this, of course, is Baldwin's language too and the story can be seen as a confessional work of some honesty. For the protagonist recognizes that his success has in part been generated by a refusal to be identified too closely with the misery of his people, by associating himself, on the contrary, with those responsible for their suffering. It has also been dependent on his refusal to grant any ambiguity to French racial attitudes. France had removed the cataract from his eyes, with respect to America, at the cost of a moral myopia with regard to French attitudes.

A brief return to America reminds him that there his life is a concession offered to him by whites. But a conversation with his French director also reminds him that suffering is not a black prerogative. For he had lost a wife and son in the war and knows the weight of history as well as the black American. The real American sin is presented as an innocence of history, a failure to perceive that the past demands a price from the present. And this is a message which Baldwin himself felt increasingly obliged to underline as his career developed.

11 James Baldwin, Going to Meet the Man (New York: 1966), p. 76.

12 Ibid., p. 127.

13 Ibid., p. 129. 
For Baldwin, Europe's function was precisely to release him from an identity which was no more than a projection of his racial inheritance. It was not, as LeRoi Jones was later to imply, that he wished to deny his colour but rather that he recognized the danger implicit in allowing public symbols of oppression or resistance to stand as adequate expressions of the self. As he said in his introduction to Nobody Knows My Name,

In America, the colour of my skin had stood between myself and me; in Europe, that barrier was down. Nothing is more desirable than to be released from an affliction, but nothing is more frightening than to be divested of a crutch. It turned out that the question of who I was was not solved because I had removed myself from the social forces which menaced me - anyway, those forces had become interior, and I had dragged them across the ocean with me. The question of who I was had at last become a personal question, and the answer was to be found in me. ${ }^{14}$

For it was Baldwin's assumption that the question of colour, crucially important on a moral level, concealed a more fundamental problem, the problem of self. And it is in that sense that he felt most American.

But he negotiates a privileged position for himself by claiming an American identity (while naturally disavowing the guilt for a prejudice which he did not originate and for a history which he played no part in determining), and simultaneously embracing a Negro identity (while declining the cultural temporizing and disabling pathology which he otherwise identifies as the natural inheritance of the black American). Both American and Negro search endlessly for identity. Only Baldwin, in the eye of the storm, realizes that it resides in stillness, in an acceptance, not of injustice nor of public roles, but of the authenticity of the self. His failure lies in his inability to reveal the authenticating process at work. Sexuality is clearly a part of it; in some way, supposedly, it tells the truth that the intellect denies. It offers a vital clue, he feels, both to the American need to dramatize innocence and to the real roots of prejudice. In his essay "Nobody Knows My Name," he coyly hints that desegregation battles have to do with "political power and ... with sex." ${ }^{15}$ Now, on an obvious level, he is clearly right. It was certainly never an argument about educational theories. But the link between that observation and the obsessive question of identity is not so clear. Meanwhile his own sexual ambiguity was itself a confusing factor, acceptance for him meaning the difficult task of accepting the real nature of his bisexuality, abandoning illusion for reality.

On the face of it the American problem with regard to sex was somewhat different. It was that sexuality had so often been presented as an absolute, as a metaphor for evil or anarchy, or, alternatively, utopian bliss, that it

14 Baldwin, Nobody Knows My Name, p. II. 15 Ibid., p. 87 . 
could not be so easily integrated into a realistic model of society. Its metaphoric weight was simply too great. But for Baldwin acceptance implied precisely that elevation of sex into metaphor, so that in virtually all of his work it stands either as an image of exploitation and abuse, or of an innocence with the power to transform social reality: sex as weapon, sex as redemption. In other words he is never more American than in his symbolic perception of sexuality, and what he presents as a kind of emotional realism is in fact a familiar form of sentimentality. It can be found just as easily in Hemingway, in Tennessee Williams, and in Norman Mailer and is no more sophisticated there, except that Mailer, whom Baldwin actually attacked for his sentimentality, purports to see sex as a dialectical term. Baldwin, in struggling to escape the sexual myths which surround the Negro in America, has simply succumbed to others.

He suggests that Wright placed violence where sex should have been, because he was unable to analyse the real nature of the rage which he perceived; but Baldwin himself endows sex with a brutal physicality which is in effect a simple transposition of social violence. Having claimed in his essays that it is principal, in his novels he presents it as agent, while the ambiguities of sexual contact, in part an expression of self, in part a surrender of self, in part aggression, in part submission, become an enactment of the ambivalence implied in the self's confrontation with society and the tensions of racial relationships. For if in suppressing the Negro, white Americans were in fact "burying ... the unspeakably dark, guilty, erotic past which the Protestant fathers made him bury," ${ }^{16}$ then the release of that erotic self should serve to heal the wound opened up by that denial of the whole man. And Baldwin was by no means alone in this assumption. What he adds is the presumption that the existence of the Negro has facilitated this disruption of identity, that he has collaborated in a myth of black sexual potency. The risk is that in releasing this sexuality in his own work he is in danger of endorsing the metaphoric presumptions of those Protestant fathers or, as bad, generating a false image of reconciliation.

In a graceless essay called "Alas, Poor Richard," following Richard Wright's death, he asserted that "the war in the breast between blackness and whiteness which caused Richard such pain, need not be a war. It is a war which just as it denies both the heights and the depths of our natures, takes, and has taken visibly and invisibly, as many white lives as black ones." For him, Wright was " among the most illustrious victims of this war." ${ }^{17}$ Borrowing one of Wright's favourite phrases, he had, he suggested,

16 Ibid., p. I69.

17 Ibid. 
wandered in a no man's land between black and white. The act of reconciliation simply lay beyond Wright's imagination. But what, then, does Baldwin offer? Only, it appears, the fact that whiteness has lost its power and that blackness will soon do so. Thus the crucial act of reconciliation will take place in the moral sensibility of the Negro. But to be made flesh, however, it must assume a reality beyond that privileged environment. And the only way in which he can dramatize it is in the literal embrace of black and white, a coition which, like that implied, but mercifully not enacted, at the end of Hawthorne's The House of the Seven Gables, will produce a moral synthesis. The trouble is that, for Baldwin, history cannot be so easily propitiated by simple images of sexual union.

For Baldwin, society is bound together by fear of our unknown selves. In other words, he offers us a neat reversal of the Lockean model. Men form society not to protect their freedom but to evade it. The notion is a Freudian one, so it is perhaps not surprising that the force he invokes to neutralize this process in his work is sexuality. This becomes the key to a real sense of community. The sentimentality of such a conviction is clear and may account for the real evasions which are to be found at the heart of so much of his own work. For social evil is thus seen as deriving from a desire for order and a fear of "our unknown selves... which can save us - "from the evil that is in the world." 18 Indeed by this logic the victim creates himself by accepting the need for social structure and granting it his acquiescence, when all the time "our humanity is our burden, our life; we need not battle for it; we need only to do what is infinitely more difficult - that is, accept it." 19

In the case of his attack on Native Son, he is offering a severe misreading, for far from being trapped within sociological generalizations, far from reducing complexity to simplicity and failing to engage the dangerous but liberating freedom of the individual, the genuinely subversive quality of that novel lies not in its attack on American society but in its conviction that individual action and the individual mind are not socially determined or socially bound. It is true that Wright's novel was a curiously schizophrenic work, with the individualistic drive of the narrative operating against an adjectival insistence on constriction and the deterministic weight implied by its sectional headings: Fear, Flight, Fate. It is equally true that, if events constitute successive stages in the liberation of the sensibility, they are also, by inverse law, stages in the diminishing world of social possibilities. But Baldwin was saddled with the same paradox. He wishes

18 Baldwin, Notes of a Native Son, p. 15 .

19 Ibid., p. I7.

AM.ST.-2 
to presume both that the self is real and pre-social, and that it cannot exist apart from its determinants. The result is a curious and distinctive tension between what he sees as an American sensibility and a free-ranging existential self - yet another example of his manichean imagination which sees himself as the product of the Old World and the New, black and white, vengeance and love, male and female, probing intellect and liberating imagination. It is a dialectical process of which the self is the putative synthesis. And, to Baldwin, this is an American process.

To Baldwin, the objective of the novelist is to serve truth, which he defines as "a devotion to the human being, his freedom and fulfilment." To see the individual as only an image of a race is to exchange reality for symbol, a life for a cause. And this was the real target of "Everybody's Protest Novel" - the retreat into metaphor. And just as Moby Dick was not to be understood either as type or as emblem, so the individual's reality lies outside his availability as public symbol. Baldwin could already feel the pressure of the public role he was inevitably offered and which he felt the need to resist. "What is today offered as his [the black writer's] Responsibility," he said, "is, when he believes it, his corruption and our loss." ${ }^{20}$ Curiously, Native Son's vulnerability to Baldwin's criticism lay less in the element of protest, which is the source of its central ambiguity, than in the vague mythologizing of the social impulse which Bigger Thomas feels. The edge of his newly-discovered identity blurs at the very moment of its coalescence. Baldwin suggests that American uncertainty about identity, and American disregard for the identity of others, derive from a contempt for history and historical process. Doubtful of historical logic, the American has tended to distrust time and to value experience - to assume that identity therefore is the product of events outside of time. A name is no more than the emblem of a man until it is claimed in action. The result is a social formlessness which masquerades as freedom but actually smacks of anarchy. And this breeds a Hemingwayesque pragmatic morality which is as likely to validate racism as anything else. It is, he suggests, an American confusion to think that it is possible to consider the person apart from all the forces which have produced him, since American history turns on the abstraction of the individual from his social and cultural setting. And yet this is precisely Baldwin's assumption, since, as we have seen above, when it serves his purpose he too posits the existence of a primary self outside of and unaffected by history. This, indeed, is a clue to a basic contradiction in his position which enables him both to use the moral self

20 Ibid., p. I I. 
to indict the social world and the social world to explain the collapse of self.

The recurring pain to which Baldwin avers is the alienation from self and from the cultural experience of the Negro, an alienation which is not neutralized by expatriation, as this intensifies the guilt and adds a further level of ambiguity since now he must battle for possession of an American identity which, if the source of his pain, is also the key to its transcendence. As he puts it in a $195^{\circ}$ essay, "Encounter on the Seine,"

To accept the reality of his being an American becomes a matter involving his integrity and his greatest hopes, for only by accepting this reality can he hope to make articulate to himself or to others the uniqueness of his experience, and to set free the spirit so long anonymous and caged. ${ }^{21}$

More than this, like Wright, he felt that the black experience not merely offered a clue to American moral ambiguity but that it functioned as metaphor, that " in white Americans he finds reflected - repeated, as it were, in a higher key - his tensions, his terrors, his tenderness" and that " in this need to establish himself in relation to his past he is most American, that this depthless alienation from oneself and one's people is, in sum, the American experience." 22

Having previously argued, in his essay on the protest novel, against metaphoric reductivism, he now strains, as expatriate, to transform his own experience into an emblem of dispossession in precisely the same way that Wright had done in a series of works starting with Native Son and running through "The Man Who Lived Underground" and The Outsider. Where he does try to establish a distinction it is that between the social and the metaphysical image, yet this is a distinction which he finds it difficult to sustain. It now turns out that his real rejection of Wright's novel lies in what he takes to be the inaccuracy of its portrait, in its faulty sociology, a conviction that the problem is being engaged too soon, at a level which denies not so much the complexity of the Negro, as that of an essential human nature. For he feels that "the battle is elsewhere. It proceeds far from us in the heat and horror and pain of life itself where all men are betrayed by greed and guilt and blood lust and where no man's hands are clean." ${ }^{23}$ It remains unexamined since, as Camus realized, the logic of this position is that if all men are guilty then all men are innocent. If the sociological approach implies the possibility of facile solutions then assertions of an immutable human nature, generating social action, leave one with the sentimentalities of evil and innocence, with desperate images

21 Ibid., p. 102.

22 Ibid., p. 104.

23 Ibid., p. 35 . 
such as that which concludes but scarcely resolves Steinbeck's The Grapes of Wrath, in which social realities are invited to defer before the reassertion of human goodness. For this was a paradox he was not ready to engage, indeed has never engaged, since he has continued to dramatize human action as a battle between good and evil, a battle which he believes to characterize American political and cultural presumptions. Out of the sociological frying pan and into the metaphysical fire. Knowing that " anyone who insists on remaining in a state of innocence long after that innocence is dead, turns himself into a monster," ${ }^{24}$ his puritan mentality continues to play with manichean ideas.

The essence of his contradictions was exposed very effectively in a conversation between Baldwin and Margaret Mead which took place in 1970 - a discussion in which the anthropologist acts as a useful restraining influence on the writer's sentimentalities and on his increasingly casual use of language. Baldwin was intent on establishing an historical guilt, incurred by the act of enslavement, but inherited by white Americans of the present. In this respect, he admitted himself to be something of an Old Testament prophet. But he also wished to offer the possibility of absolution, and the resultant contradiction between an ineradicable guilt and a necessary grace, which has characterized so much of his work, was carefully exposed by Margaret Mead. Speaking of the process of enslavement of blacks, he describes it as "the crime which is spoken of in the Bible, the sin against the Holy Ghost which cannot be forgiven." ${ }^{25}$ The exchange which followed reveals his tendency to let language and imagery outstrip his convictions:

MEAD: Then we've nowhere to go.

Baldwin: No, we have atonement.

MEAD: Not for the sin against the Holy Ghost.

BaLdwin: No?

MEAD: I mean, after all, you were once a theologian. ... And the point about the sin against the Holy Ghost is that -

BALDwIN: Is that it cannot be forgiven.

MEAD: So if you state a crime as impossible of forgiveness you've doomed everyone.

BaLdwin: No. I don't think I was as merciless as the Old Testament prophets. But I do agree with Malcolm X, that sin demands atonement.

MEAD: Whose sin? I mean, you're making racial guilt -

BALDWIN: No.

MEAD: Yes. You are.

BALDwIN : I'm not talking about race. I'm talking about the fact.

24 Ibid., p. 148.

25 James Baldwin and Margaret Mead, A Rap On Race (London: 1972), p. 186. 
MEAD: But you are. ... You're taking an Old Testament position, that the sins of the fathers are visited on their children.

Baldwin: They are.

MEAD: The consequences are visited on the children.

BalDwin: It's the same thing, isn't it?

Mead: No, it's not the same thing at all. Because it's one thing to say, All right, I'm suffering for what my fathers did -

Baldwin: I don't mean that, I don't mean that! I don't mean that at all! I mean something else! I mean something which I may not be able to get to ...

MEAD: $\quad .$. but when you talk about atonement you're talking about people who weren't born when this was committed.

Baldwin: No. I mean the recognition of where one finds oneself in time or history or now. ... After all, I'm not guiltless, either. I sold my brothers or my sisters -

MeAd: When did you?

Baldwin: Oh, a thousand years ago, it doesn't make any difference.

MEAD: It does make a difference. I think if one takes that position it's absolutely hopeless. I will not accept any guilt for what anybody else did. I will accept guilt for what I did myself. ${ }^{26}$

Jean-Paul Sartre makes a similar point in Anti-Semite and Jew when he observes that " if one is going to reproach little children for the sins of their grandfathers, one must first of all have a very primitive conception of what constitutes responsibility." 27

What Baldwin's comments to Margaret Mead demonstrate is a desire, evident throughout his published works, to present history as present reality, to establish a social responsibility which, because he chooses to dramatize it in terms of sin and guilt, he is unable to establish as an active principle. The Old Testament prophet denies the efficacy of New Testament grace. The writer who wishes to establish a racial indictment is thus inhibited from dramatizing the need for racial reconciliation which is a conviction which he holds with equal force. His desire to establish his belief that individuals are responsible moral creatures is simultaneously undermined by his conviction that their crime is ineradicable and human beings ineluctably wicked. The problem does not reside in language alone, but in his own terrible ambivalences which lead him to accuse and defend, condemn and rescue with equal conviction. The deficiency is an intellectual one.

Even now, in one mood, he sees a solution in some kind of symbolic union of black and white for which he can find no historic justification

26 Ibid., pp. $186-87$.

27 Jean-Paul Sartre, Anti-Semite and Jew, trans. G. J. Becker (New York: 1965), p. I6. 
342 C. W. E. Bigsby

and for which he can establish no social mechanism. When asked, some twenty-five years after his first essay, how he meant to go about securing his solution to the problem, his reply was simply "I don't know yet." And then, slipping into the opposite mood, which has always been the other side to this sentimental vision, he offered the only solution which he could see: "Blow it up." ${ }^{28}$

28 Baldwin and Mead, A Rap On Race, p. $25^{\circ}$. 